\title{
A user's guide to radon priority areas, examples from Ireland
}

\author{
Méabh B. Hughes', Javier Elío² and Quentin G. Crowley'* \\ 'Department of Geology, School of Natural Sciences, Trinity College, Dublin, Ireland; '2Department of Planning, \\ Aalborg University Copenhagen, Copenhagen, Denmark
}

\section{Abstract}

Exposure to radon over time has significant detrimental effects on human health. Approximately 226,000 annual radon-related deaths have been reported from 66 countries (1). Many countries have a radon action plan, in order to reduce the harmful effects of radon exposure on the general public. Maps are routinely used to assist with mitigation strategies and delineate areas of priority regulation. Standard regulations in the European Union include the requirement for workplaces to test and the requirement to have reduction methods in newly built homes. Such laws are assigned systematically to areas that are understood to have high values of indoor radon. This article demonstrates that the boundaries of radon priority areas may vary, depending on the data set and methods used. We propose a table and a decision matrix to assist in choosing the most appropriate visual aid according to the purpose for which the map is to be used. We conclude that no single radon map is suitable to fit all objectives, and some maps are more suitable than others depending on the purpose.

Keywords: indoor radon; radon maps; radon mapping objectives; spatial resolution; geogenic data.

$\mathrm{M}$ itigating the level of radioactive exposure to citizens has been the task of many countries for decades (2-4). The radioactive exposure mitigated against includes natural (e.g. radon) and anthropogenic (e.g. nuclear energy and medical x-rays) sources. This article focuses on the mapping and modelling of radon gas and its possible negative health effects on the general public, which accounts for approximately $50 \%$ of a person's radiation dose (5). Radon is a natural gas that poses a negligible health risk when outdoors, with radon concentrations in the order of 10 's Bq m${ }^{-3}$ (6). However, radon can accumulate inside dwellings and caves, typically from 100 's $\mathrm{Bq} \mathrm{m}^{-3}$ to 1,000 's Bq m${ }^{-3}$, respectively $(7,8)$. Exposure to higher radon concentrations is linked to the development of health ailments, the most commonly recognized of which is lung cancer (9-14). Other diseases (e.g. skin cancer, non-Hodgkin's lymphoma, stomach cancer and brain cancer) may be correlated with radon exposure, and any causative links are still under investigation (15-18).

Radon ( $\mathrm{Rn})$ is the largest contributor of natural radioactivity to the general public. The ${ }^{222} \mathrm{Rn}$ isotope is considered the primary radon risk source indoors (19-21) due to its relatively long half-life (i.e. 3.8 days). ${ }^{222} \mathrm{Rn}$ is commonly used indistinctly in the legislation, and the definitions of radon priority areas (RPAs) are based on this isotope. Therefore, we use this criterion in the text; however, another natural radon isotope that may pose a risk in particular circumstances is thoron (i.e. ${ }^{220} \mathrm{Rn}$; half-life of
$55.6 \mathrm{~s}$ ), and it is attracting more attention with the development of the first thoron maps (22-24). ${ }^{222} \mathrm{Rn},{ }^{220} \mathrm{Rn}$ and their daughter products emit alpha particles, damaging lung tissue if inhaled $(10,25-27) .{ }^{222} \mathrm{Rn}$ and ${ }^{220} \mathrm{Rn}$ concentrations naturally vary geo-spatially, influenced by soil geochemistry, soil permeability and underlying geogenic factors (28-32). Furthermore, indoor radon (hereafter referred to as InRn) accumulation is also influenced by weather/climate, housing and occupancy characteristics (33-37).

The issue of radioactivity, including radon, is recognized by the European Union (EU), which has resulted in the development of an EU Directive (Basic Safety Standards, BSS) that obliges member states to assign RPAs. The EU Directive aims to protect both individuals and the collective from radiation exposure (2). The aforementioned directive requires a National Radon Action Plan (NRAP) to be established, which addresses radon risk in water, domestic dwellings, public buildings and workplaces from radon ingress, whether from the soil, water or building materials. Furthermore, this directive requires that effective radon mitigation and prevention measures are established for new buildings. It legally binds the member states to identify areas where 'the radon concentration in a significant number of buildings is expected to exceed the relevant national reference level'. However, the definitions of 'a significant amount of buildings' and 'the reference level' are not clarified, allowing for different methods to be used. In 
turn, this can lead to radon risk maps, which are not directly comparable, and different evaluations needed to assess the success of each Action Plan (38).

Therefore, the Directive obligates EU member states to create radon maps where the spatial distribution of radon levels is presented. The radon maps are consequently useful for: (1) predicting regions with non-acceptable levels at home/workplace, (2) targeting public awareness, (3) estimating radiation dose from radon and (4) studying the health effects of radon. The tools needed to achieve each objective may be different, and thus, different maps would be required simultaneously (39). The different types of radon hazard index maps should be distinguished to avoid confusion (40).

In Ireland, the 1997 Building Regulations state that high radon can occur in any part of the country (41). However, only buildings in high radon areas (HRA) are legally obliged to include mitigation measures in their construction, for example, a membrane and a subsurface radon extraction device (i.e. sump) should be provided. In other areas, a subsurface radon extraction device should be installed in case it needs to be activated at a future time. Other buildings do not have specific guidance in the 1997 regulations. In relation to gamma radiation for building materials, the Radiological Protection Act 1991 (42) states, in Regulation 67, that building materials should not emit more than $1 \mathrm{mSv}$ of gamma radiation per year. Schedule 10 gives an indicative list of building materials with the potential to emit gamma radiation (42).

Building developers and employers in HRA are legally obliged to prevent, remediate and ensure that their buildings/workplaces are below the radon reference level (hereafter referred to as RL). HRA receive priority regulation, which is necessary to reduce the harmful effects of natural radiation cost-effectively. The most recently established national RL decided by the EPA in Ireland should not exceed $300 \mathrm{~Bq} \mathrm{~m}^{-3}$ in homes as well as workplaces (42). Currently, the EPA decided a more conservative value, which, keeping with legislation, is $200 \mathrm{~Bq} \mathrm{~m}{ }^{-3}$ for homes and $300 \mathrm{~Bq} \mathrm{~m}^{-3}$ for workplaces. As such, in Ireland, HRA for dwellings are defined as 'any area where it is predicted that $10 \%$ or more of homes will exceed the reference level of 200 Becquerels per cubic meter $\left(\mathrm{Bq} \mathrm{m}^{-3}\right)^{\prime}$ (43). The initiatives to reduce radon from accumulating in a building could be considered a primary prevention method, whereas targeting public awareness and mitigation in HRA could be regarded as secondary and tertiary prevention measures.

\section{Radon priority areas and mapping}

RPAs signify areas that may have a higher radon risk than others. Such sites are prioritised for public awareness initiatives and are specially protected through the building regulations. RPAs are legally defined and can be determined using different data and criteria, which can lead to differing RPA boundaries in the same location (44). Without appropriate strategy and communication, such discrepancies can lead to loss in fidelity of information, loss of credibility, and diminished public trust and interest.

Numerous methods have been used by different countries in Europe (Table 1). An in-depth report of natural radiation and the various techniques can be read in the European Atlas of Natural Radiation (45). The studies referred to in Table 1 utilize different concepts of radon risk, but all are valid. These concepts range from an area having a probability of InRn over the RL to the likelihood of developing lung cancer in a given region. In the following sections, we discuss the most relevant approaches.

\section{Maps based on indoor radon measurements}

\section{Probabilistic map}

This method uses the concept that a percentage of houses in a certain area does/does not exceed an RL. If more than a certain number (i.e. a threshold) of homes in the area are above the RL, then the site is deemed an RPA (44). For example, an InRn map of Switzerland assigned areas a percentage representing the probability of exceeding the $\mathrm{RL}$ of $300 \mathrm{~Bq} \mathrm{~m}^{-3}$, and the regions allocated with a higher rate are the RPAs (46).

\section{Average concentration map}

The concept of this method is that an area will have an average $\mathrm{InRn}$ value resulting from all of the $\mathrm{InRn}$ values for the zone. For example, Estonia averaged the InRn per administrative unit of communes to visualize the spatial distribution of InRn (47). Another example is Italy's map (48), which has determined the average InRn according to region. Austria and Switzerland have other examples where areas with a mean indoor value above the RL are deemed an RPA (44).

\section{Radioactive dose map}

This technique aims to map the distribution of the radioactive dose received by people in a zone. Furthermore, this approach seeks to correlate InRn exposure to the amount of radioactive exposure available to be received in an area. For example, the Slovak Republic deployed the method of converting the population-weighted arithmetic mean of the InRn measurements into an estimated radioactive dose for each district (49) and considered the different types of houses in this process.

\section{Maps based solely on geogenic factors}

Information on geogenic characteristics, such as geology, Quaternary geology, soil type, permeability, structural geology (faults and fractures) and aquifer type, has been utilized to improve the predictions of radon 
Table 1. Various methods and resolutions of radon risk mapping seen from a selection of representative European countries

\begin{tabular}{|c|c|c|c|c|c|}
\hline Country & Reference level & Objectives & Methods & Resolution & Reference \\
\hline \multirow[b]{2}{*}{ Austria } & \multirow[b]{2}{*}{$\begin{array}{l}200 \text { and } 400 \\
\mathrm{~Bq} \mathrm{m^{-3 }}\end{array}$} & \multirow{2}{*}{$\begin{array}{l}\text { Divide the country into three } \\
\text { classes, that is, average annual } \\
\text { concentration }<200,200-400 \\
\text { and }>400 \mathrm{~Bq} \mathrm{~m}{ }^{-3}\end{array}$} & $\begin{array}{l}\text { Annual mean radon concentration } \\
\text { in a standard situation }\end{array}$ & $\begin{array}{l}\text { Administrative level } \\
\text { (i.e. municipality) }\end{array}$ & $(72)$ \\
\hline & & & $\begin{array}{l}\text { Bayesian statistics, combining } \\
\text { indoor radon measurements } \\
\text { (standard situation) and geology }\end{array}$ & $\begin{array}{l}\text { Geological classes } \\
\text { (scale 1:500.000) }\end{array}$ & $(73)$ \\
\hline $\begin{array}{l}\text { Belgium } \\
\text { (Wallon region) }\end{array}$ & $400 \mathrm{~Bq} \mathrm{~m} \mathrm{~m}^{-3}$ & $\begin{array}{l}\text { Percentage of dwellings above } \\
\text { the } \mathrm{RL} \text { taking into account } \\
\text { geological information }\end{array}$ & $\begin{array}{l}\text { Moving average between geological } \\
\text { units }\end{array}$ & $\mathrm{I} \mathrm{km} \times \mathrm{I} \mathrm{km}$ & $(74)$ \\
\hline $\begin{array}{l}\text { United } \\
\text { Kingdom }\end{array}$ & $200 \mathrm{~Bq} \mathrm{~m}^{-3}$ & $\begin{array}{l}\text { Percentage of houses above } \\
\text { the } R L \text { taking into account } \\
\text { geological information. } \\
\text { Radon priority areas (RPA) } \\
\text { when } P[\ln R n>R L] \geq 1 \%\end{array}$ & $\begin{array}{l}\text { Lognormal model, corrections to } \\
\text { account for year-to-year and random } \\
\text { variations (i.e. Bayesian statistics) }\end{array}$ & Grids I km $\times$ I km & $(75-77)$ \\
\hline Norway & $200 \mathrm{~Bq} \mathrm{~m}^{-3}$ & $\begin{array}{l}\text { Percentage of houses above } \\
\text { the RL based on indoor radon } \\
\text { and geological information } \\
\text { (bedrock and Quaternary } \\
\text { geology). RPA when } P[\operatorname{lnRn}> \\
\text { RL] } \geq 20 \% \text {. }\end{array}$ & $\begin{array}{l}\text { Classify geological polygons } \\
\text { according to local (polygon) } \\
\text { statistics or national (class) statistics }\end{array}$ & Geological polygons & $(5 \mathrm{I})$ \\
\hline \multirow[t]{3}{*}{ Ireland } & $200 \mathrm{~Bq} \mathrm{~m}^{-3}$ & $\begin{array}{l}\text { Percentage of houses above } \\
\text { the } R L \text { based solely on indoor } \\
\text { radon measurements. RPA } \\
\text { when } P[\ln R n>\text { R.L.] } \geq 10 \%\end{array}$ & Lognormal model & Grids $10 \times 10 \mathrm{~km}$ & $(56)$ \\
\hline & $200 \mathrm{~Bq} \mathrm{~m}^{-3}$ & $\begin{array}{l}\text { Percentage of houses above the } \\
\text { RL based on indoor radon and } \\
\text { geological information (i.e. } \\
\text { bedrock geology, Quaternary } \\
\text { geology, subsoil permeability } \\
\text { and soil permeability). RPA } \\
\text { when P[InRn }>\text { RL] } \geq 10 \%\end{array}$ & Logistic regression model & Grids I $\times 1 \mathrm{~km}$ & $(3 I)$ \\
\hline & - & $\begin{array}{l}\text { Estimation of radon-related } \\
\text { lung cancer cases }\end{array}$ & $\begin{array}{l}\text { Dose estimation based on average } \\
\text { concentrations (i.e. block averages } \\
\text { after ordinary kriging) }\end{array}$ & $\begin{array}{l}\text { Administrative level } \\
\text { (i.e. electoral division) }\end{array}$ & (39) \\
\hline Malta & $100 \mathrm{~Bq} \mathrm{~m}{ }^{-3}$ & $\begin{array}{l}\text { Display the indoor radon } \\
\text { concentration values }\end{array}$ & $\begin{array}{l}\text { Average of geometric mean annual } \\
\text { indoor radon gas concentration } \\
\text { values for each sampling point }\end{array}$ & Grids $5 \times 5 \mathrm{~km}$ & $(78)$ \\
\hline
\end{tabular}

Average indoor radon values have been grouped to administrative levels, as seen for Austria and Ireland. Grids of I $\mathrm{km}^{2}$ have been utilized in Belgium, the UK and Ireland. Austria and Norway used geological units. Several reference levels operate across the member states. These range from $100 \mathrm{~Bq}^{-3}$ in Malta, $200 \mathrm{~Bq} \mathrm{~m}^{-3}$ in Ireland, Norway and the UK, and $400 \mathrm{~Bq} \mathrm{~m}^{-3}$ in Belgium. Adapted from Ref. (57).

mapping $(50,51)$. Considering that radon arising from the earth is the primary source of InRn (4), understanding the spatial distribution and variation of geological factors is useful when mapping radon. Two main concepts are defined regarding the mapping of naturally available radon. The first concept is the Geogenic Radon Hazard Index (GRHI), which incorporates data of available geogenic entities. The second concept is the Geogenic Radon Potential (GRP), which is radon that is naturally available in an area and is mainly influenced by the soil properties, hydrology and geology (40). However, the use of GRP for radon mapping is more limited due to the availability of the necessary data; these concepts are discussed in detail in (40).

\section{Radon potential maps}

GRP mapping aims to define boundaries according to the availability of radon entering a building. The most commonly adopted method is the 'Czech method' (52), which collects in situ soil-gas radon and soil permeability measurements. The combination of soil-gas radon information and soil permeability values results in a GRP, giving an index which represents the potential of finding elevated radon levels in a building on the surveyed site.

\section{Spatial resolution of radon maps}

Many different resolutions of radon maps have been used, each of which have their pros and cons. 


\section{Regular grids}

Regular grids are used, for example $500 \mathrm{~m}^{2}$ and $5 \mathrm{~km}^{2}$ in Montenegro and $10 \mathrm{~km}^{2}$ in Albania $(53,54)$. Many factors may be considered when deciding which size of a grid to use. For example, if creating a map using InRn data, the number of samples in a given area is incredibly relevant. Grids for rural areas may need to be larger to have a sufficient data set, whereas urban areas inherently have more InRn measurements, allowing for smaller grids to be used (53). Smaller grids are better at representing the high spatial variation of radon and should be preferentially used when the size of a data set allows it.

\section{Administrative boundaries}

In other cases, radon is mapped according to municipalities, counties or even electoral divisions $(47-49,55)$. In each case, the data for mapping radon risk are grouped within each boundary type. The chosen boundary type influences each map's outcome in a similar way that different grid sizes dictate the outcome. An advantage of this approach is that it is easier to engage the public to identify with an area. However, difficulties arise in mapping according to administrative boundaries, especially if using geogenic data. Using administrative boundaries for mapping makes it arduous to compare neighbouring countries when different methods and concepts are used, as is the case for all European countries (38).

Ireland as a case study

\section{Maps based on indoor radon values}

\section{Probabilistic map}

The legislative radon risk map in Ireland is a probabilistic map (56). It defines an area as radon prone if $10 \%$ or more of houses are above the RL (Fig. 1a). The probabilistic radon (a) EPA InRn Map

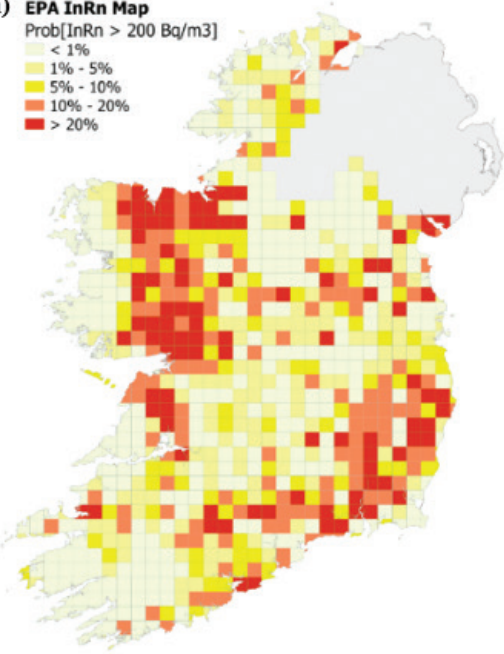

(d) New InRn Map

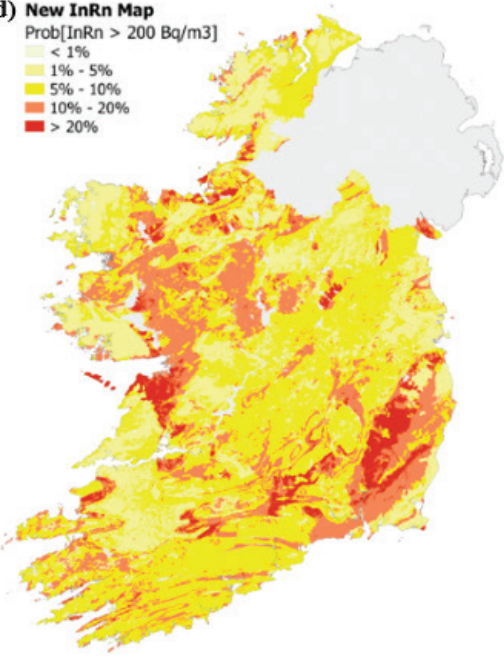

(b) Average Concentration

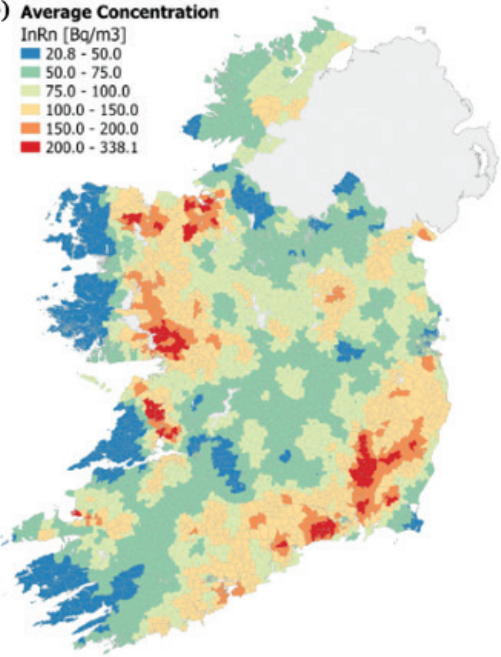

(e) Lung Cancer Incidence Map

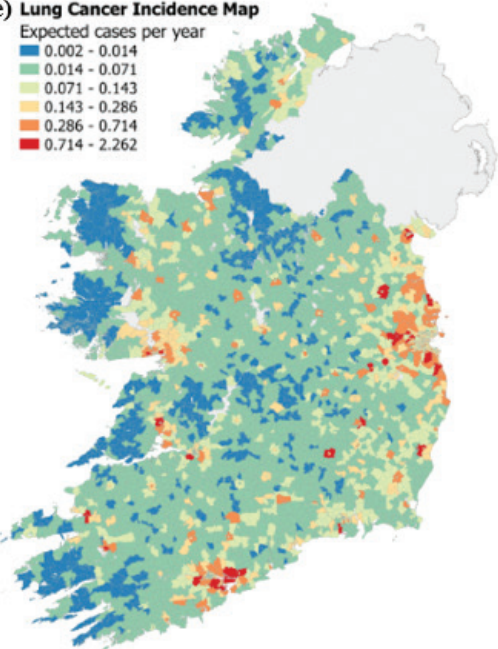

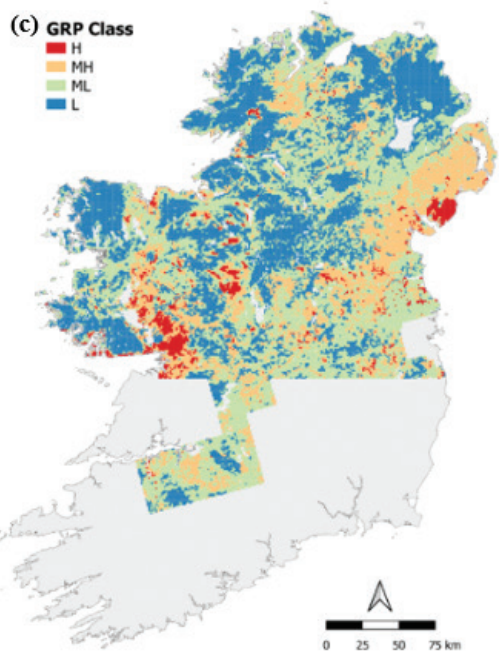

Fig. 1. (a) Legislative indoor radon probability map (56). (b) Indoor radon average concentration map (39). (c) Radon potential map (61). (d) Indoor radon probability map (31). (e) Radon-related modeled lung cancer incidence map (39). 
risk method is useful for defining areas that are generally more prone to radon. Since InRn measurements from private dwellings were used, it may be unsuitable for workplaces and other building types due to the differences in radon behaviour in different building types (57). The advantage of using this mapping style is that measurements of InRn are used, allowing for a direct representation of an area's radon category status.

The Irish Environmental Protection Agency (EPA) protocol for measuring indoor radon includes taking at least two measurements in two separate rooms of a house using a CR-39 detector over a 3-month measurement period. The results are then seasonally corrected to an annual average (58).

\section{Average concentration map}

The average concentration map illustrates the mean InRn level for an area [Fig. 1b (39)], allowing the map user to identify zones with higher radon levels. This helps to get an estimate of the typical InRn value for a specific area. Furthermore, this map is convenient for linking with health effects and epidemiological studies of lung cancer. An advantage of this map type is that it uses direct measurements of InRn, which allows for a true and accurate representation of the radon value in a given area. The mean InRn concentrations were collected from homes using the EPA protocol (58). Furthermore, the measurements were performed mainly from the ground floor of houses, and it is assumed that the results are representative of multistorey buildings (39).

\section{Radon-related lung cancer cases}

Maps made to include the radioactive dose due to radon allow for distinguishing areas based on the expected lung cancer incidence (39). In Ref. (39), two models were analysed, the first being a linear no-threshold model and the second being a dose-effect model, both of which resulted in similar numbers of estimated lung cancer cases (216246, 257-249, 220-251 and 316-317 cases for the linear model and dose effect model, respectively). Comparable results, approximately 300 annual radon-related lung cancer cases were reported by presenters at Ireland's 14 th and 15 th National Radon Forum $(59,60)$. This mapping procedure targets the concept that lung cancer incident rates differ between areas. A map made using this method incorporated information on the population size and distribution [Fig. 1e (39)]. The resulting map may be useful for initiatives to reduce the long-term adverse health effects of radon exposure. Specifically, it could delineate areas designated as possessing a higher lung cancer incidence rate, therefore identifying where the collective population at a higher risk are situated. The main advantage is that the long-term aim of the radon action plan is targeted, which is to reduce the number of lung diseases resulting from Rn exposure. However, a disadvantage arises: high population areas are more likely to be designated as an RPA. As a result, this method would only be appropriate for identifying larger populations at risk and is inappropriate for detecting individuals at high radon risk.

The radon-related lung cancer incidence was estimated over a lifetime of 70 years, and it is assumed that a person lives in the same place. Furthermore, the effect on smokers and non-smokers is assumed to be the same (39).

\section{Adding geogenic data}

Maps that integrate geological information utilize the fact that geology impacts radon values [Fig. 1d (31)]. Radon maps, which include geogenic data, are useful for improving mapping, especially in areas with a low amount of InRn data. Visual aids made using this methodology could also be practical for land redesignation in low populated areas. An advantage of this map type is that it employs information on the radon source and its pathway into a building. A drawback of using geogenic maps for radon mapping is that the geological maps scale may cause deviations of radon designation boundaries.

\section{Maps based solely on geogenic factors}

\section{Radon potential map}

The concept targeted by GRP maps is that the source and the pathway of radon gas determine the InRn risk. Such maps are useful for understanding the radon risk in any area. Advantages include that they are appropriate for any building type: workplace, public and domestic dwellings. These visual aids are also useful in low populated areas where there may be a lack of InRn data to make other radon risk map types. An example is shown in Fig. $1 \mathrm{c}(61)$.

Furthermore, in situ GRP surveys can be done rapidly at a local scale (62). It is important to note that the GRP map shown in Fig. 1c used a method that was created for a local scale and applied it to a regional/national scale, that is, the method was used differently from how it was designed. In theory, these maps are independent of building characteristics. However, the building characteristics do have an influence on the infiltration rate and behaviour of radon within a house $(57,63)$.

\section{Spatial resolution}

The boundaries of the radon risk categories on a map can change significantly depending on the spatial resolution used. Figure 2 demonstrates several probabilistic radon risk maps, with the only variable for sub-figures (a) to (f) being the spatial resolution. The probabilistic map is shown on the left side of Fig. 2 [sourced from (31)]; it was created using InRn data and several 

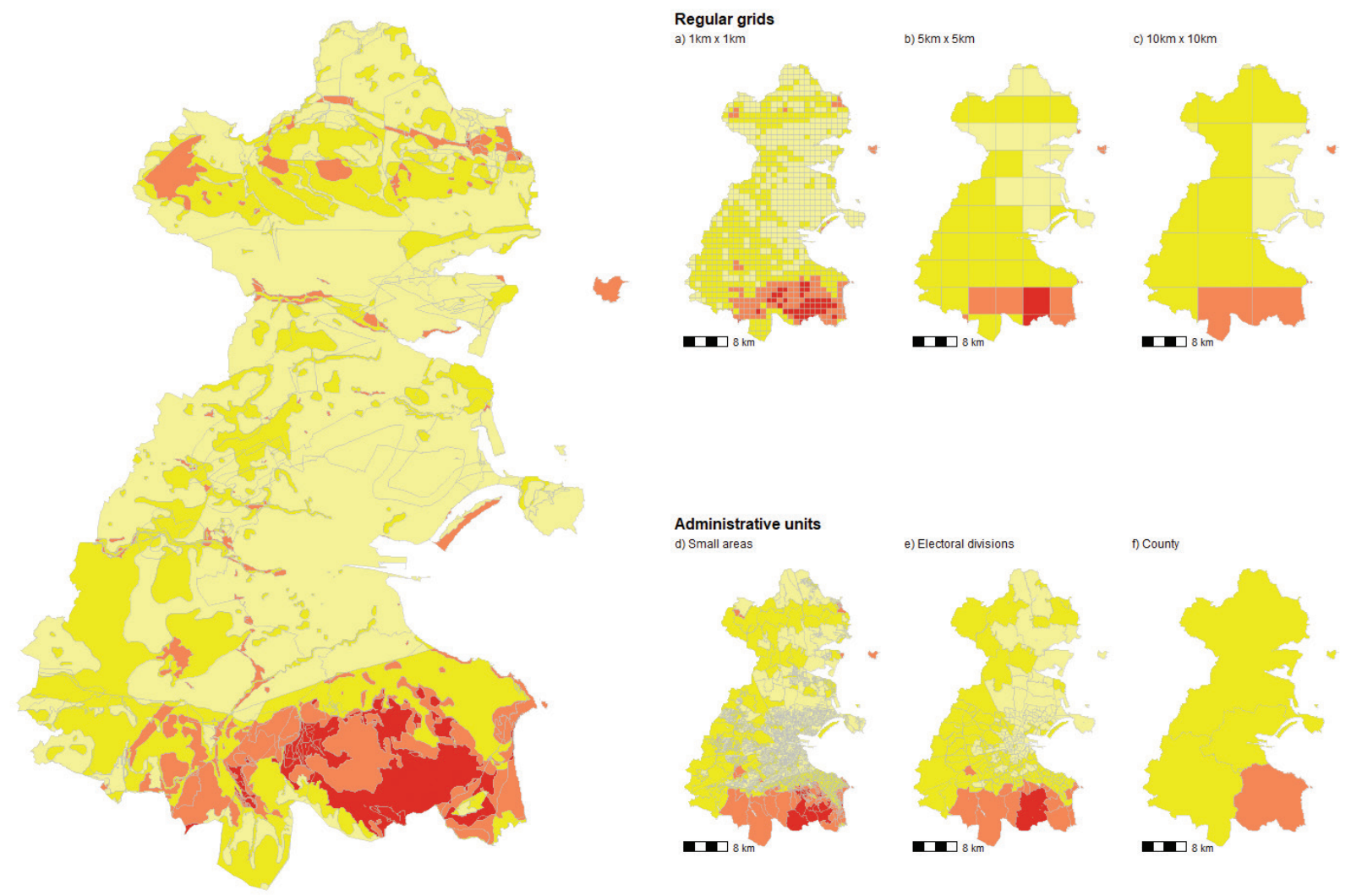

Fig. 2. Radon probabilistic map of County Dublin, Ireland. The various maps (a) to (f) in this figure have been made using the same input data. The spatial resolution varies between the maps. Maps (a) to (c) show how the radon probability boundaries change from grid sizes of $1 \mathrm{~km}^{2}, 5 \mathrm{~km}^{2}$ and $10 \mathrm{~km}^{2}$. Maps (d) to (f) show how the boundaries change depending on which administrative boundary is used, that is, small areas, electoral division and county region. For comparison, the large map of Dublin on the left is sourced from (31) and was created using both indoor radon data and several geogenic data types.

geogenic data sets. Distinctly, the addition of geogenic data reveals areas with higher radon, particularly in the southeast of County Dublin. The sub-figures (a) to (c) on Fig. 2 illustrate how different grid sizes (i.e. $1 \mathrm{~km}^{2}, 5$ $\mathrm{km}^{2}$ and $10 \mathrm{~km}^{2}$, respectively) impact the radon categories despite the same input data InRn being used. Noticeably, the $1 \mathrm{~km}^{2}$ grid shows that there are areas in the north of County Dublin which have high InRn values. The sub-figures (d) to (f) on Fig. 2 illustrate how radon categories for zones change according to spatial resolution (i.e. small areas, electoral divisions and county regions) despite the same input data (i.e. InRn) being used. Importantly, smaller units allow for the spatial variability of radon be represented, which is essential for protecting individuals against high radon exposure.

\section{Regular boundaries}

The benefit of using a $10 \mathrm{~km}^{2}$ grid is that InRn data can be grouped, allowing for a more significant sample set, which is favourable for statistics. To elaborate, using larger grid sizes permits smaller areas with low-density data sets to be aggregated and assigned a category as opposed to being left blank. However, lower-resolution grids do not represent the high variability of radon within the area, that is, some parts of the grid may be more prone to radon. Even within a $10 \mathrm{~km}^{2}$ area, radon concentrations can vary due to radon source variability and subsurface transportation routes (faults, fractures and soil permeability).

The use of smaller grids (i.e. $1 \mathrm{~km}^{2}$ ) permits radon variability in any area to be represented more accurately. However, a high number of data points would be needed. This would be an issue in areas with a low population density. However, the need for large amounts of InRn data can be overcome by using alternative data sets, such as geogenic factors, for the models.

\section{Administrative boundaries}

Choosing to use administrative units for radon mapping makes it easier to link with other statistics (e.g. cancer 
registry and population density). This also allows for better public awareness initiatives as it is easier to identify areas where people live.

As for the case with the gridded areas, larger administrative boundaries, such as municipalities or counties, make it easier to have a bigger sample set, which is more statistically favourable. In contrast, smaller areas (areas generally comprising between 80 and 120 dwellings) or Electoral Divisions in Ireland are better at representing the spatial variability of radon concentrations. However, in the latter, a higher density of data would be needed.

Overall, maps based on InRn data are useful for targeting domestic dwellings that may be over the RL. Although the InRn measurements taken decades ago may not still be representative of InRn measures today, especially when the building style has changed, which impacts how radon accumulates inside. In contrast, radon maps based solely on geogenic data are more consistent through time because the geology in an area does not change for extended periods, although Geological Surveys may upgrade the geological maps when more information is available.

\section{Discussion}

It is important to mitigate against radon exposure, given that it accounts for the highest proportion of natural radioactivity to which the general public are exposed (5, 13). Maps as visual aids are a valuable resource and planning tool to prioritise certain areas to reduce radon exposure to citizens. However, choosing the most appropriate map is a complicated procedure that reflects the issues intricate nature. There are many factors to consider when deciding on a national or local radon mitigation strategy. These include if the purpose is to reduce Rn in workplaces, homes or public spaces, or if the aim is to reduce the resulting lung cancer incidence from Rn exposure. As well as considering the purpose of the strategy, the ease of using available data sets may be a determining factor on which map to use. Considering this intricacy, we attempt to make the decision process simpler by proposing a table (Table 2) and a decision matrix (Fig. 3) below.

We propose a process, or method, to approach the task of deciding which visual aid to use based on (a) the purpose and (b) the available data.

In Table 2, the different Rn maps are tabulated according to time and cost-efficiency. We have indicated if each map type is representative at a local and large scale. Additionally, the suitability of the maps for protecting the collective or the individual is shown. The last column of Table 2 outlines the suggested use of each map type. The decision matrix (Fig. 3) simplifies the EU and national Rn mitigation objectives. These objectives are rationalized into several initiatives, available data sets and sources.
Finally, considering the above counterparts, the output options are indicated for the data available.

The decision matrix, however, does not indicate the time and cost-efficiency of each option, although this is indicated in Table 2. Further difficulties are outlined in the decision matrix. Figure 3 does not capture that any data used may be updated over time, which could lead to discrepancies in the resulting maps. This issue could be accounted for by automating the process where the data set could be updated every few years or over a set amount of time. Another disadvantage not depicted in Fig. 3 is that the accessibility to building characteristics may be difficult. The amount of time spent indoors and in different $\mathrm{Rn}$ areas has not been integrated into most of the reviewed maps. The exception is Fig. 1e, which assumes that the time spent indoors is $80 \%$ (39).

There is compelling evidence of a synergistic effect between radon and smoking in contributing to lung cancer development $(64,65)$. Smokers in high radon risk areas are more likely to develop lung cancer than smokers in low radon exposure areas $(66,67)$. Furthermore, (66) reported an $11 \%$ increase in lung cancer, with InRn increasing by $100 \mathrm{~Bq} \mathrm{~m}^{-3}$. Hampson et al. (68) surveyed people regarding radon risk perception, noting that $32 \%$ of people knew little or nothing about radon. Butler et al. (69) suggested that people may perceive a higher risk of lung cancer when exposure to smoking and radon is combined. Such information (69) could prove vital in strategising more effective public outreach, engagement and respiratory health awareness programmes. Explicitly, it may be a practical approach to combine the public health initiative of smoking awareness with radon awareness.

Both smoking and radon exposure are systematic problems in respiratory health. However, the approaches for managing these two issues are compartmentalised. Public awareness regarding the risks related to tobacco smoking is extensive, whereas the risk awareness related to radon is relatively low. Considering that radon is the leading cause of lung cancer after smoking and the synergistic effect of developing lung cancer when smoking and radon exposure is combined, it may be beneficial to amalgamate these campaigns. Conceptualising smoking demographics onto a map may be challenging. However, it may be better to simultaneously communicate the effect of these two issues on respiratory health. Our lungs can be affected by radon as well as smoking. As such, incorporating this information would allow for a more holistic approach to combating respiratory health issues.

In some cases, this is starting to be done. For example, the World Health Organisation's International Agency for Research on Cancer (IARC) has developed an initiative implemented by the European Commission to inform 


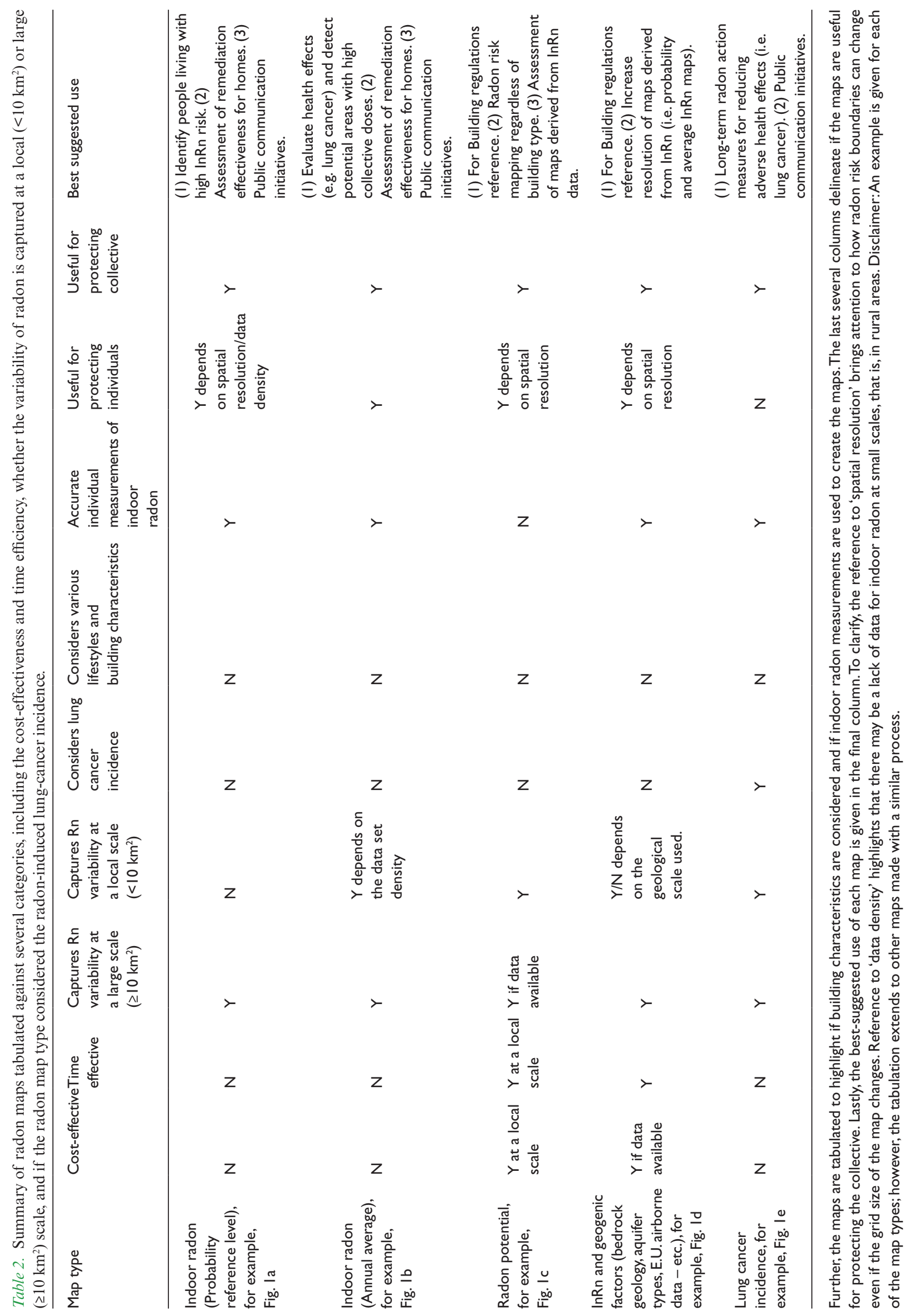




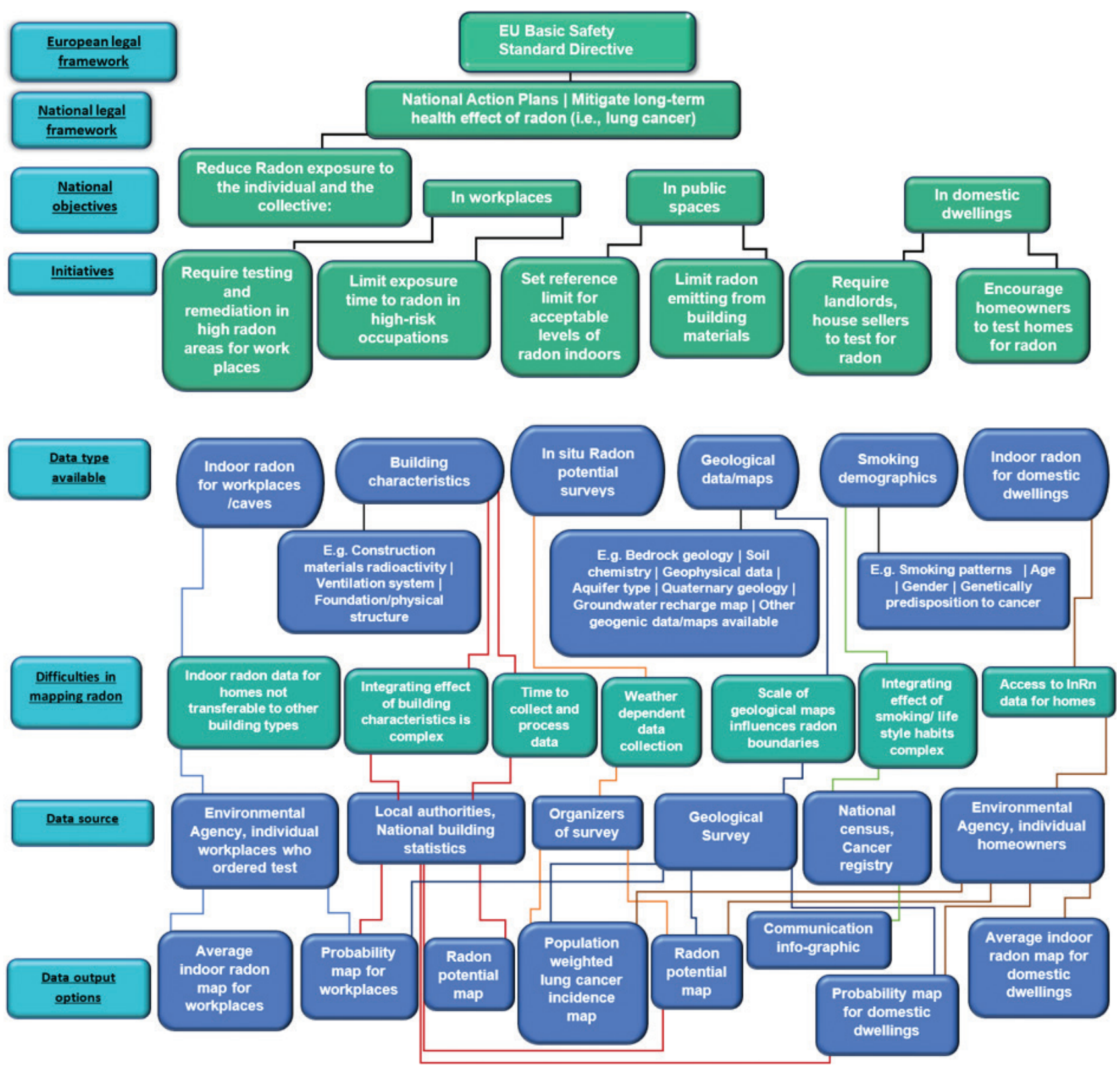

Fig. 3. Decision matrix to aid in choosing an appropriate radon map best suited to its purpose. Several frameworks and objectives, as well as initiatives, are indicated in the top half of the decision key. The bottom half gathers the range of data types available and how they are linked to the various data output options. Difficulties associated with and some potential sources of each data group are given. The different coloured lines are simply to make the connections between categories easier to observe.

people how to reduce cancer risk, which includes reducing exposure to radon (70). As part of the IARC initiative, the Irish Cancer Society has included radon on a public communication list of 12 ways to reduce cancer risk (71).

\section{Conclusion}

In this article, a review of some potential visual aids for radon mapping is made, focusing on Ireland's various radon maps already published. We have assumed that the indoor radon data were representative for mapping the target estimate (e.g. probability, average and collective dose) and that the maps were properly developed. In this sense, we do not discuss the methods of how maps are devised, but in how they are used.

Visual aids can make the decision process more manageable, considering where to target regulations or public awareness initiatives. The resources available and the radon map's purpose should be at the core of the decision process when deciding on a plan. Firstly, the spatial resolution can influence the map's outcome even if the same 
input data are used (Fig. 2). When considering spatial resolutions, a large scale is good for national-level initiatives, such as delineating RPAs for requiring workplaces to have radon barriers/sumps. A small/local spatial resolution would be useful for building developers or homeowners who want to remediate their homes.

Secondly, the different methods used do not map the same thing concerning radon exposure. For example, probabilistic maps aim to identify areas that are more prone to $\mathrm{InRn}$, while the average concentration radon maps aim to distinguish regions according to their mean concentration. These maps would help target radon awareness campaigns for individual homeowners. If the aim is to protect the collective and rank citizens' risk of developing radon-induced lung cancer, then choosing a lung cancer incidence map would be appropriate.

Finally, the GRP maps aim to provide information on the amount of soil-gas radon available to become $\mathrm{InRn}$ in the area, which is particularly useful for redesignating land or when constructing a new building. Depending on the purpose of which one wants a radon risk map to be used, one map type may be more favourable than the other, and one visual aid will not be appropriately suitable to fit all strategies.

\section{Conflict of interest and funding}

The authors declare no potential conflicts of interest. This work has been financed by the Student Universal Support Ireland (SUSI) to $\mathrm{MH}$.

\section{References}

1. Gaskin J, Coyle D, Whyte J, Krewksi D. Global estimate of lung cancer mortality attributable to residential radon. Environ Health Perspec 2018; 126: 057009. doi: 10.1289/EHP2503

2. European Commission. Council directive 2013/59/Euratom. Official Journal of the European Union 2013;2013/59/EURATOM. Publications Office of the European Union, Luxembourg.

3. United Nations Scientific Committee on the Effects of Atomic Radiation. Report of the United Nations Scientific Committee on the Effects of Atomic Radiation (UNSCEAR) 1958: Report to the General Assembly, with Scientific Annexes. 1958:229. United Nations, Vienna. https://doi. org/10.18356/0b0b1bc1-en.

4. World Health Organisation. International radon project survey on radon guidelines, programmes and activities. World Health Organisation, Geneva, 2007.

5. Monty C. UNSCEAR report 2000: sources and effects of ionizing radiation. J Radiol Protect 2000; 21. doi: $10.8 / 0952-4746 / 21 / 1 / 609$

6. Gunning GA. Studies of radon in Ireland: Outdoor levels, detector intercomparison and school remediation methods, [thesis] Trinity College (Dublin, Ireland). School of Physics, 2016.

7. Darby S, Hill D, Auvinen A, Barros-Dios JM, Baysson H, Bochicchio F, et al. Radon in homes and risk of lung cancer: collaborative analysis of individual data from 13 European case-control studies. BMJ 2005; 330: 223. doi: 10.1136/ bmj.38308.477650.63
8. Duffy JT, Madden JS, Mackin GM, McGarry AT, Colgan PA. A reconnaissance survey of radon in show caves in Ireland. Environment International 1996; 22: 415-23. doi: 10.6/ S0160-4120(96)00140-7

9. Kreuzer, M., Fenske, N., Schnelzer, M. and Walsh, L., Lung cancer risk at low radon exposure rates in German uranium miners. British journal of cancer 2015; 113: 1367-9. doi: 10.1038/ bjc. 2015.324

10. Lorenzo-González M, Torres-Durán M, Barbosa-Lorenzo R, Provencio-Pulla M, Barros-Dios JM, Ruano-Ravina A. Radon exposure: a major cause of lung cancer. Expert review of respiratory medicine 2019; 13: 839-50. doi: 10.1080/17476348.2019.1645599

11. Ludewig P, Lorenser E. Untersuchung der Grubenluft in den Schneeberger Gruben auf den Gehalt an Radiumemanation. Zeitschrift Für Physik 1924; 22: 178-85. doi: 10.1007/BF01328120

12. Vahakangas KH, Metcalf RA, Welsh JA, Bennett WP, Harris CC, Samet JM, et al. Mutations of p53 and ras genes in radon-associated lung cancer from uranium miners. The Lancet 1992; 339: 576-80. doi: 10.1016/0140-6736(92)90866-2

13. World Health Organisation. W.H.O Handbook on indoor radon: a public health perspective, World Health Organisation, Geneva, 2009.

14. Yarmoshenko IV, Malinovsky GP. Lung cancer mortality and radon exposure in Russia. Nukleonika 2016; 61: 263-8. doi: 10.1515/nuka-2016-0044

15. Ha M, Hwang S, Kang S, Park N-W, Chang B-U, Kim Y. Geographical correlations between indoor radon concentration and risks of lung cancer, non-Hodgkin's Lymphoma, and Leukemia during 1999-2008 in Korea. Int J Environ Res Public Health 2017; 14: 344. doi: 10.3390/ijerph14040344

16. López-Abente G, Núñez O, Fernández-Navarro P, Barros-Dios JM, Martín-Méndez I, Bel-Lan A, et al. Residential radon and cancer mortality in Galicia, Spain. Sci Total Environ 2018; 610 611: 1125-32. doi: 10.1016/j.scitotenv.2017.08.144

17. Monastero RN, Meliker JR. Incidence of brain and spinal cord cancer and county-level radon levels in New Jersey, Wisconsin, Minnesota, Pennsylvania, and Iowa, USA. Environ Geochem Health 2020; 42: 389-95. doi: 10.1007/ s10653-019-00368-6

18. Ruano-Ravina A, Dacosta-Urbieta A, Miguel Barros-Dios J, T Kelsey K. Radon exposure and tumors of the central nervous system. Gaceta Sanitaria 2018; 32(6): 567-575. doi: 10.1016/j. gaceta.2017.01.002

19. Rosario AS, Wichmann H-E. Environmental pollutants | Radon. In: Laurent GJ, Shapiro SD, editors. Encyclopedia of respiratory medicine. Oxford: Academic Press, 2006, p. 120-5.

20. Schwela D. Pollution, indoor air. In: Wexler P, editor. Encyclopedia of toxicology. 3rd ed. Oxford: Academic Press, 2014; p. 1003-17.

21. Tommasino L. Radiochemical methods | Radon. In: Worsfold P, Townshend A, Poole C, editors. Encyclopedia of analytical science (2nd ed.). Oxford: Elsevier, 2005; p. 32-44.

22. Lucchetti C, Briganti A, Castelluccio M, Galli G, Santilli $\mathrm{S}$, Soligo $\mathrm{M}$, et al. Integrating radon and thoron flux data with gamma radiation mapping in radon-prone areas. The case of volcanic outcrops in a highly-urbanized city (Roma, Italy). J Environ Radioact 2019; 202: 41-50. doi: 10.1016/j. jenvrad.2019.02.004

23. Vuckovic B, Gulan L, Milenkovic B, Stajic JM, Milic G. Indoor radon and thoron concentrations in some towns of central and South Serbia. J Environ Manage 2016; 183: 938-44. doi: 10.1016/j.jenvman.2016.09.053 
24. Avinash PR, Rajesh S, Kerur BR, et al. Radon, thoron and their progeny concentration variations in dwellings of Gogi region, Yadgir district of Karnataka, India. J Radioanal Nucl Chem 302, 1321-1326, 2014. https://doi.org/10.1007/s10967-014-3608-x

25. Krewski D, Lubin JH, Zielinsk JM, Alavanja M, Catalan VS, Field RW, et al. Residential Radon and risk of lung cancer: a combined analysis of 7 North American case-control studies. Epidemiology 2019; 16(2): 137-45. doi: 10.1097/01. ede.0000152522.80261.e3

26. Samet JM. Radon and lung cancer. JNCI 1989; 81: 745-58. doi: 10.1093/jnci/81.10.745

27. Taylor JA, Watson MA, Devereux TR, Michels RY, Saccomanno $\mathrm{G}$, Anderson M, et al. p53 mutation hotspot in radon-associated lung cancer. The Lancet 1994; 343: 86-7. doi: 10.1016/ S0140-6736(94)90818-4

28. Je H-K, Kang C, Chon H-T. A preliminary study on soil-gas radon geochemistry according to different bedrock geology in Korea. Environ Geochem Health 1999; 21: 117-31. doi: 10.1023/A:1006613016217

29. Gallagher V, Knights KV, Carey S, Glennon M, Scanlon R. Atlas of topsoil geochemistry of the Northern Counties of Ireland: Data from the Tellus and Tellus border projects. Geological Survey of Ireland, Dublin, 2016.

30. Young ME, Knights KV, Smyth D, Glennon MM, Scanlon RP, Gallagher V. The Tellus geochemical surveys, results and applications. Unearthed: Impacts of the Tellus Surveys of the North of Ireland, Royal Irish Academy, Dublin, 2016; p. 33-52. doi: 10.3318/978-1-908996-88-6.ch3

31. Elío J, Crowley Q, Scanlon R, Hodgson J, Long S. Logistic regression model for detecting radon prone areas in Ireland. Sci Total Environ 2017; 181: 599-600. doi: 10.1016/j.scitotenv.2017.05.071

32. Ferreira A, Daraktchieva Z. Indoor radon measurements in south west England explained by topsoil and stream sediment geochemistry, airborne gamma-ray spectroscopy and geology. Elsevier J Environ Radioact 2018. doi: 10.1016/j. jenvrad.2016.05.007

33. Akbari K, Mahmoudi J, Ghanbari M. Influence of indoor air conditions on radon concentration in a detached house. J Environ Radioact 2013; 116: 166-73. doi: 10.1016/j.jenvrad.2012.08.013

34. Casal-Mouriño A, Ruano-Ravina A, Torres-Durán M, ParenteLamelas I, Provencio-Pulla M, Castro-Añón O, et al. Lung cancer survival in never-smokers and exposure to residential radon: results of the LCRINS study. Cancer Letters 2020; 487: 21-6. doi: 10.1016/j.canlet.2020.05.022

35. Lantz PM, Mendez D, Philbert MA. Radon, smoking, and lung cancer: the need to refocus radon control policy. Am J Publ Health 2013; 103: 443-7. doi: 10.2105/AJPH.2012.300926

36. Muntean LE, Cosma C, Cucos A, Dicu T, Moldovan DV. Assessment of annual and seasonal variation of indoor radon levels in dwelling houses from Alba County, Romania. Rom Journ Phys 2014; 59: 163-71.

37. Rigby JG, La Pointe DD. Wind and barometric pressure effects on radon in two mitigated houses. The 1993 international radon conference; p. 61-8, University of Nevada, Reno, 1993.

38. Tollefsen T, Cinelli G, Bossew P, Gruber V, De Cort M. From the European indoor radon map towards an atlas of natural radiation. Radiat Protect Dosim 2014; 162: 129-34. doi: 10.1093/rpd/ncu244

39. Elío J, Crowley Q, Scanlon R, Hodgson J, Zgaga L. Estimation of residential radon exposure and definition of Radon Priority Areas based on expected lung cancer incidence. Environ Int 2018; 114: 69-76. doi: 10.1016/j.envint.2018.02.025

40. Bossew P, Cinelli G, Ciotoli G, Crowley Q, Cort M, Elío J, et al. Development of a Geogenic Radon hazard index - concept, history, experiences. Int J Environ Res Publ Health 2020; 17: 4134. doi: 10.3390/ijerph17114134

41. Building Regulations. Building Regulations. Statutory Instruments No. 497 of 1997, Irish statute, Government of Ireland, Dublin, 1997.

42. Radiological Protection Act 1991 (Ionising Radiation) regulations. Statutory Instruments Ireland, S.I. No. 30 of 2019. Oireachtas, Government of Ireland, Dublin, 2019.

43. Environmental Protection Agency Ireland. Radon map: Environmental Protection Agency, Ireland. 2020. Available from: https://www.epa.ie/radiation/radonmap/ [cited 6 October 2021].

44. Bossew P. Radon Priority Areas - definition, estimation and uncertainty. Nucl Technol Radiat Protect 2018; 33: 11. doi: 10.2298/NTRP180515011B

45. Cinelli G, de C, Tollefsen T, (Eds.), European atlas of natural radiation, Publication Office of the European Union, Lexembourg, 2019.

46. Kropat G, Bochud F, Jaboyedoff M, Laedermann J-P, Murith $\mathrm{C}$, Palacios M, et al. Major influencing factors of indoor radon concentrations in Switzerland. J Environ Radioact 2014; 129: 7-22. doi: 10.1016/j.jenvrad.2013.11.010

47. Petersell V, Gustav Å. Radon risk Map of Estonia: explanatory text to the radon risk map set of Estonia at scale of 1: 500000 . Eesti Geoloogiakeskus, Tallinn, 2005

48. Bochicchio F, Campos-Venuti G, Piermattei S, Nuccetelli C, Risica S, Tommasino L, et al. Annual average and seasonal variations of residential radon concentration for all the Italian Regions. Radiat Meas 2005: 686-94. doi: 10.1016/j. radmeas.2004.12.023

49. Ministry of the Environment of Slovak Republic. State of the Environment. Report of the Slovak Republic, Bratislava, 2003.

50. Friedmann H, Baumgartner A, Bernreiter M, Gräser J, Gruber $\mathrm{V}$, Kabrt F, et al. Indoor radon, geogenic radon surrogates and geology - investigations on their correlation. J Environ Radioact 2017; 166: 382-9. doi: 10.1016/j.jenvrad.2016.04.028

51. Watson RJ, Smethurst MA, Ganerød GV, Finne I, Rudjord AL. The use of mapped geology as a predictor of radon potential in Norway. J Environ Radioact 2017; 166: 341-54. doi: 10.1016/j. jenvrad.2016.05.031

52. Neznal M, Neznal M, Matolin M, Barnet I, Miksova J. The new method for assessing the radon risk of building sites. Czech Geological Institute, Prague, 2004.

53. Antovic N, Vukotic P, Zekic R, Svrkota R, Ilic R. Indoor radon concentrations in urban settlements on the Montenegrin Coast. Radiat Meas 2007; 42: 1573-9. doi: 10.1016/j. radmeas.2007.06.003

54. Tushe KB, Bylyku E, Xhixha G, Dhoqina P, Daci B, Cfarku F, et al. First step towards the geographical distribution of indoor radon in dwellings in Albania. Radiation protection dosimetry, Oxford University Press, Oxford, United Kingdom, 172, no. 4, 2016; p. 488-95.

55. Andersen CE, Ulbak K, Damkjær A, Gravesen P. Radon i danske boliger. Kortlægning Af Lands-, Amts-Og Kommuneværdier 2001. København : Sundhedsstyrelsen, Statens Institut for Strålehygiejne, $132 \mathrm{p}$.

56. Fennell SG, Mackin GM, Madden JS, McGarry AT, Duffy JT, O'colmain M, et al. Radon in dwellings: the Irish National Radon survey. Radiological Protection Institute of Ireland, Dublin, 2002.

57. Cinelli G, Tollefsen T, Bossew P, Gruber V, Bogucarskis K, De Felice L, et al. Digital version of the European Atlas of natural radiation. J Environ Radioact 2019; 196: 240-52. doi: 10.1016/j. jenvrad.2018.02.008 
58. EPA. Environmental Protection Agency of Ireland Protocol for the measurement of radon in homes and workplaces, Environmental Protection Agency of Ireland, Wexford, 2019.

59. Hickey C. Setting the Scene. National Radon forum 2019. Department of Communications, Climate Action and Environment, Dublin, Ireland (DCCAE).

60. Walsh PM, National Cancer Registry, Environmental Protection Agency. A revision of the number of radon-related lung cancers in Ireland:National Radon Forum preliminary results, Wexford, 2017.

61. Elío J, Crowley Q, Scanlon R, Hodgson J, Long S, Cooper M, et al. Application of airborne radiometric surveys for large-scale geogenic radon potential classification. J Eur Radon Assoc 2020; 1. doi: 10.35815/radon.v1.4358

62. Elío J, Quentin C, Ray S, Jim H, Stephanie L. Rapid radon potential classification using soil-gas radon measurements in the Cooley Peninsula, County Louth, Ireland. Environmental Earth Sciences 2019; 78. doi: 10.1007/s12665-019-8339-4.1-16

63. Bossew P. Determination of radon prone areas by optimized binary classification. J Environ Radioact 2014; 129: 121-32. doi: 10.1016/j.jenvrad.2013.12.015

64. Leuraud K, Schnelzer M, Tomasek L, Hunter N, Timarche M, Grosche B, et al. Radon, smoking and lung cancer risk: results of a joint analysis of three European Case-control studies among Uranium miners. Radiat Res 2011; 176: 375-87. doi: $10.2307 / 41318201$

65. Meenakshi C, Mohankumar MN. Synergistic effect of radon in blood cells of smokers - an in vitro study. Mutat Res: Genet Toxicol Environ Mutagen 2013; 757: 79-82. doi: 10.1016/j. mrgentox.2013.06.018

66. Li C, Wang C, Yu J, Fan Y, Liu D, Zhou W, et al. Residential Radon and histological types of lung cancer: a meta-analysis of case-control studies. Int J Environ Res Public Health 2020; 17: 1457. doi: $10.3390 /$ ijerph 17041457

67. Park EJ, Lee H, Kim HC, Sheen SS, Koh SB, Park KS, et al. Residential Radon exposure and cigarette smoking in association with lung cancer: a matched case-control study in Korea. Int J Environ Res Publ Health 2020; 17: 2946. doi: 10.3390/ ijerph17082946

68. Hampson SE, Andrews JA, Lee ME, Foster LS, Glasgow RE, Liechtenstein E. Lay Understanding of synergistic risk: the case of Radon and cigarette smoking. Risk Analysis 1998; 18: $343-$ 50. doi: 10.1111/j.1539-6924.1998.tb01300.x

69. Butler KM, Huntington-Moskos L, Rayens MK, Wiggins AT, Hahn EJ. Perceived synergistic risk for lung cancer after environmental report-back study on home exposure to tobacco smoke and Radon. Am J Health Promot 2018; 33: 597-600. doi: $10.1177 / 0890117118793886$

70. World Health Organisation IA for R on C. The European Code Against Cancer, World Health Organisation, Geneva, Switzerland, 2016. https://www.europeancancerleagues.org/ cancer-prevention-the-european-code-against-cancer/ [cited 6 October 2021].

71. Irish Cancer Society. 12 ways to reduce your risk of getting cancer 2016

72. Friedmann H. Final results of the Austrian Radon Project. Health Physics 2005; 89: 339-48. doi: 10.1097/01. HP. 0000167228.18113 .27

73. Friedmann H, Gröller J. An approach to improve the Austrian Radon Potential Map by Bayesian statistics. Journal of Environmental Radioactivity 2010;101:804-8. doi: 10.1016/j. jenvrad.2009.11.008.

74. Cinelli G, Tondeur F, Dehandschutter B. Development of an indoor radon risk map of the Walloon region of Belgium, integrating geological information. Environ Earth Sci 2011; 62: 809-19. doi: 10.1007/s12665-010-0568-5

75. Daraktchieva Z, Appleton J, Reese D. Radon in Northern Ireland: indicative Atlas. Centre for Radiation, Chemical and Environmental Hazards, Public Health England, Oxfordshire, 2015.

76. Miles J. Calibration and standardisation of etched track detectors. Radon Measurements By Etched Track Detectors: Applications in Radiation Protection, Earth Sciences and the Environment, World Scientific, Singapore; 1997, p. 143-154. doi: 10.1142/9789812830197_0006

77. Miles JCH, Appleton JD, Rees DM, Green BMR, Adlam KAM, Myers AH. Indicative atlas of radon in England and Wales. Chilton, Oxon: Health Protection Agency, Government of the United Kingdom, Oxfordshire, 2007.

78. Baluci C, Vincenti K, Tilluck B, Conchin S, Formosa S, Grech D. National mapping survey of indoor radon levels in the Maltese Islands (2010-2011). Malta Medical Journal, Msida 2013.

\section{*Quentin G. Crowley}

Department of Geology

School of Natural Sciences

Trinity College, Dublin 2, Ireland

Email: crowleyq@tcd.ie 